\title{
Morfostrukturní doklady ponásunového porušení Pavlovských vrchů, Vnější Západní Karpaty
}

\author{
Morphostructural evidences of post-thrust deformation of the Pavlov Hills, Outer Western \\ Carpathians
}

\author{
Martin Šutjak ${ }^{1} \rightrightarrows$, Adam Rajnoch', Rostislav Melichar', Ivo Baroň ${ }^{2}$ \\ 'Ústav stav geologických věd PřF MU, Kotlářská 2, 61137 Brno, Česká republika \\ 2 Ústav struktury a mechaniky hornin AV ČR, V Holešovičkách 94/41, 18209 Praha 8, Česká republika
}

Key words:

Outer Western Carpathians, Jurassic limestone, tectonics, strike-slip, fault

$\Xi$ 432503@mail.muni.cz

Editor:

Milan Geršl

\begin{abstract}
The article presents geomorphological and structural evidences of post-thrust limestone brittle deformation in the area of Pavlov Hills on the westernmost margin of the Outer Western Carpathians, Czech Republic. Airborne LiDAR-derived digital terrain model with $1 \mathrm{~m}$ resolution was used for this analysis, as well as aerial photographs and fieldwork. Combining these methods, we document a distinct $N$-S directed fault zone that intersects or delineates the majority of the Pavlov Hills Jurassic limestone nappe outliers. Data revealed an almost continuous fault zone of the north-south direction, which ranges from Horni Vèstonice in the North, to Mikulov in the South, and extends further south to Austria. The thrusted Jurassic limestone bodies are cut by the fault zone, which tectonically crushed the limestone in its core and cores of the secondary fault branches. The map pattern of the fault zone suggests directional anastomotic branching and reattaching with the production of lenticular tectonic slices. We interpret the fault as a prominent sinistral shear zone. This is indicated by block displacement on the Svatý kopeček Hill and also by the orientation of the accompanying subvertical Riedel shears with identified horizontal lineation. The activity of the fault zone onset tightly after the nappe thrusting at the final stages of the accretion wedge formation, which is suggested from the observed sinistral kinematics. The main movement along the fault is thus most probably of a late Miocene age.
\end{abstract}

Úvod

Rozpoznání křehké tektoniky obvykle nebývá ve flyšových horninách jednoduché vzhledem k jejich litologické jednotvárnosti - typicky rytmická střídání pískovců, prachovců a jílovců - a jejich malé odolnosti vůči zvětrávání. Avšak lokálně lze najít litologické kontrasty, které jsou pro studium křehké tektoniky velmi vhodnými markery. Takovým prostředím mohou být v kontextu Vnějších Západních Karpat např. vápencové komplexy zapracované do flyšových souvrství, nebot jsou litologicky nápadné a zároveň výrazně odolnější vůči zvětrávání. Následkem toho se výrazně morfologicky projevují, tvoří výchozy a na obnažených místech jsou dobře viditelné struktury křehkého porušení. Tuto skutečnost navíc podtrhuje jejich časté odkrytí drobnou i rozsáhlejší povrchovou těžbou, což umožňuje studovat i struktury rychle zanikající při zvětrávání.

Jedním z takových území je i oblast Pavlovských vrchů s tektonickými šupinami jurských vápenců, jejichž tektonické porušení bylo předmětem mnoha studií. Většina předválečných prací se zabývala především pozicí a vznikem tzv. „vápencových bradel“ (např. Jüttner 1933). Při dalších výzkumech pak byly detekovány zlomy, a to jak směrné (JZ-SV), tak i zlomy severojižní (Stejskal 1934, 
1935). Podrobnější pohled na zlomové struktury Pavlovských vrchů přinesli zejména mapéři a autoři zabývající se vyhodnocováním dat $\mathrm{z}$ prospekce uhlovodíků (např. Dudek, Špička 1975; Adámek 1979, 1984; Stráník et al. 1979, 1999; aj.). Dosavadní tektonické výzkumy přehledně shrnul Poul (2004, 2006), který se zabýval převážně násunovou tektonikou. Při tom rozpoznal prrítomnost zlomů směru SZ-JV, které interpretoval jako hlavní př́íčné zlomy (Poul, Melichar 2009). Naposledy částečnou studií přispěl Rajnoch (2021).

Během předchozích průzkumů byly vedle násunových ploch vymezeny i zlomy ponásunové, převážně se strmým úklonem. Mezi nejvýznamnější ponásunové zlomy definované ve výše citovaných pracích patří zejména (viz obr. 1):

- mikulovský zlom (1) severojižního směru omezující vápencová bradla ze západní strany (Čtyroký et al. 1988);

- falkensteinsko-mikulovský zlom (2) směru S-J až SSV-JJZ, který odděluje západní část vídeňské pánve od vápencových bradel (Kalášek, red. 1963);

- velkopavlovský zlom (3) směru SV-JZ, který podle Dudka a Špičky (1975) patří do skupiny mailberských zlomů z rakouské strany;

- věstonický zlom (4) směru SV-JZ, který prochází obcemi Horní Věstonice na severovýchodě a Dolní Dunajovice na jihozápadě (Čtyroký et al. 1988).

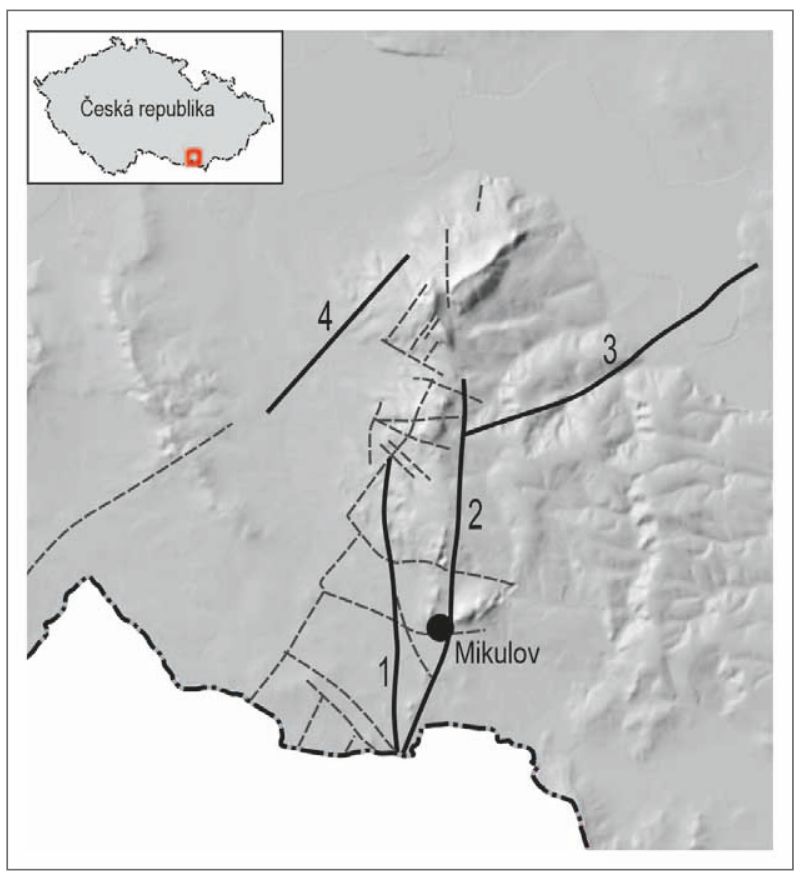

Obr. 1: Hlavní zlomy Pavlovských vrchů na podkladu stínovaného reliéfu (ČÚZK, 2021). Vysvětlivky: čárkovaně - zlomy nepojmenované; plně - zlomy pojmenované: 1 - mikulovský; 2 - falkensteinsko-mikulovský; 3 - velkopavlovský; 4 - věstonický. Fig. 1: Main faults of the Pavlov Hills visualized on the DMR (ČÚZK, 2021). Explanation: dashed line - faults without name; solid line - faults already named: 1 - Mikulov Fault; 2 - Falkenstein-Mikulov Fault; 3 - Velké Pavlovice Fault; 4 - Věstonice Fault.
Oba posledně jmenované zlomy podle seismických údajů zasahují až do fundamentu v podloží Karpat (Adámek 1979).

Cílem tohoto příspěvku je zhodnocení geologických, a zejména geomorfologických projevů křehké deformace postihující vápence v oblasti Pavlovských vrchů. Pozornost byla soustředěna především na zlom procházející Mikulovem, který protíná či omezuje většinu jurských vápencových bradel.

\section{Metodika}

Pro studium morfologie terénu a křehkého porušení vápenců byly využity jednak metody dálkového průzkumu Země (LiDaR, letecké snímky), jednak strukturně geologická rekognoskace takto nalezených struktur v terénu.

- LiDaR (Light Detection and Ranging) umožňuje sestavení velmi podrobného digitálního modelu reliéfu bez stromové vegetace. Pro morfologická studia byl použit digitální model reliéfu (DMR) páté generace $(5 \mathrm{G})$, který je dostupný v podobě obrazu stínovaného reliéfu na datovém geoportálu Českého úřadu zeměměřického a katastrálního (ČÚZK 2021). Tato metoda byla úspěšně použita pro definování průběhu studovaného zlomu v místech, kde došlo $\mathrm{k}$ tektonickému omezení vápencových bloků s ohledem na jejich kontrastní morfologické vystupování oproti okolním flyšovým souvrstvím a tektonicky oslabeným zónám.

- Letecké snímky mohly být využity pouze v místech s obnaženým terénem. Bylo využito ortofoto z leteckého snímkování z letních období roku 2018 a 2020 (Mapy.cz 2021). Vegetace pokrývající zobrazené skalní podloží přednostně roste v místech s lepší dostupností podzemní vody. Drobné zlomové poruchy nebo zóny drcení vápenců se pak na snímcích projevují jako více či méně nápadné vegetační pásy.

- Strukturně geologická rekognoskace byla cíleně provedena u struktur vytipovaných metodami dálkového průzkumu. Byly sledovány jednak indikované zlomové plochy drobných rozměrů, př́izlomová puklinová kliváž, a zóny drcení vápencového masivu. Orientace struktur byla určována geologickým kompasem (Freiberg) ve stupních spádnicovým způsobem. Data orientace byla následně zpracována v programu StaTect (Rez 2020).

\section{Charakteristika studovaného zlomu}

Na základě analýzy digitálního modelu reliéfu a leteckých snímků byl stanoven poměrně souvislý severojižní průběh hlavního zlomu procházejícího oblastí Pavlovských vrchů (obr. 2A, B), jehož některé části byly identifikovány již dř́ve (Kalášek, red. 1963; Čtyroký et al. 1988). Nejsevernější projev tohoto zlomu byl zjištěn v místě označovaném jako Soutěska, kde je vrch Děvín na západní straně omezen rovinnou, téměř svislou stěnou zřejmě zlomového původu. V jejím jižním pokračování lze pozorovat méně výrazné omezení i na východní straně vrchu Pálava, který leží přibližně $400 \mathrm{~m}$ jižněji (obr. 2C). 


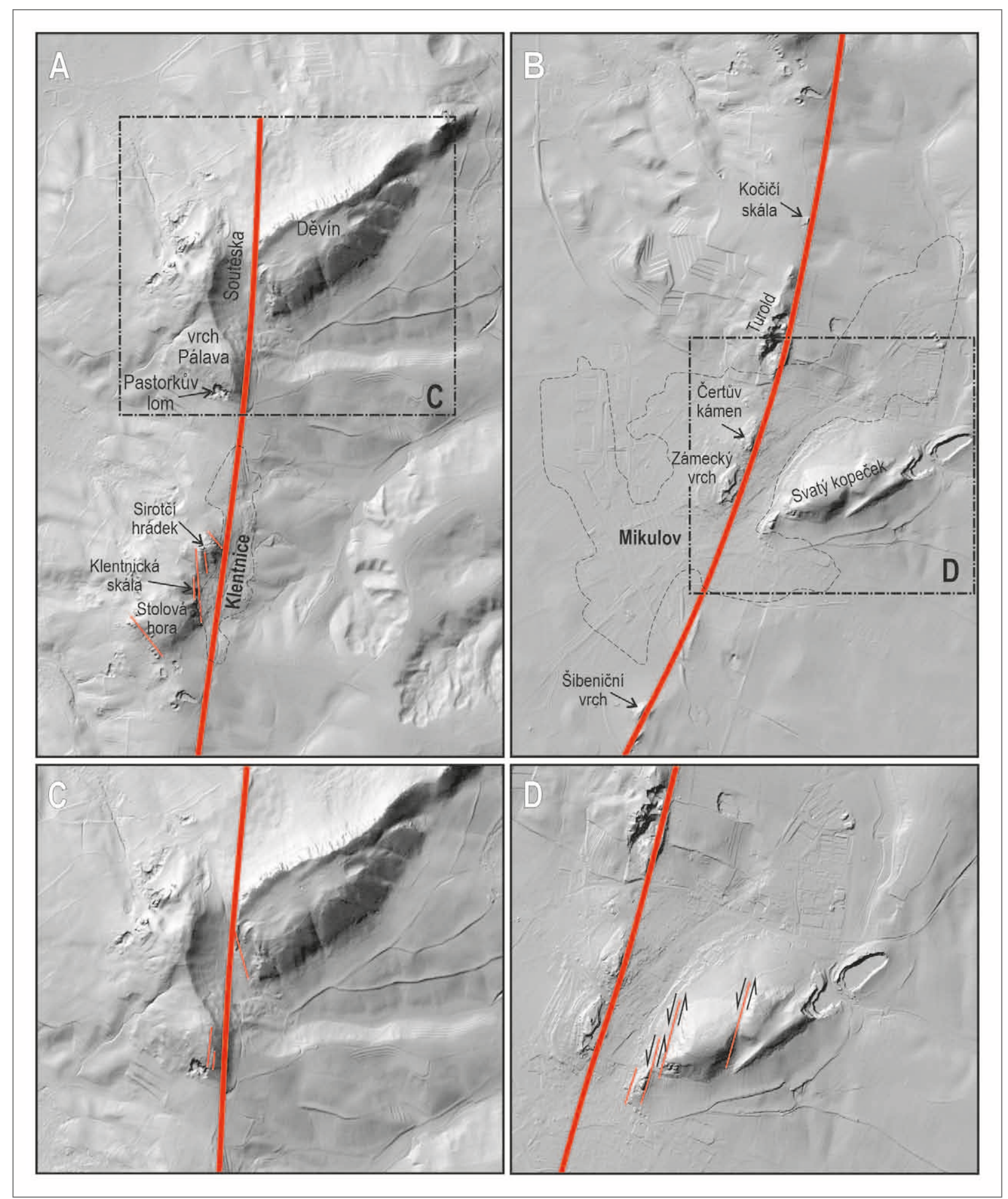

Obr. 2: Průběh studovaného zlomu na podkladu stínovaného reliéfu (ČÚZK, 2021): A - severní část, od Soutěsky po Stolovou horu; B - jižní část, od Kočičí skály až po Šibeniční vrch; C - detail průběhu zlomu v lokalitě Soutěska; D - detail průběhu zlomu v lokalitě Mikulov a doprovodných paralelních větví na lokalitě Svatý kopeček.

Fig. 2: Studied fault highlighted on the DMR base map (ČÚZK, 2021): A - northern part, from Soutěska to Stolová Hora Hill; B - southern part, from Kočičí skála to Šibenice Hill; C - close up on the fault zone in Soutěska area; D - close up to Svatý Kopeček Hill with highlighted parallel fault branches.

Další průběh zlomu lze pozorovat v obci Klentnice, kde zlom z východní strany ostře omezuje elevaci Sirotčího hrádku a částečně i Stolové hory. Dále na jih se směr zlomu mírně stáčí do směru SSV-JJZ. Přibližně $1,6 \mathrm{~km}$ jižně od Stolové hory vystupuje u hlavní cesty mezi Klentnicí a Mikulovem menší skalisko označované jako Kočičí skála. To je ve směru sledovaného zlomu výrazně protaženo. Zřejmě se jedná o tektonickou šupinu, která je z obou stran omezená větvemi zlomu. Ve stejném směru je protažený i vrch Turold, ležící v severní části města Mikulov. Další průběh zlomu lze pozorovat na východním omezení Čertova kamene a zámeckého vrchu (obr. 2D). Na našem 

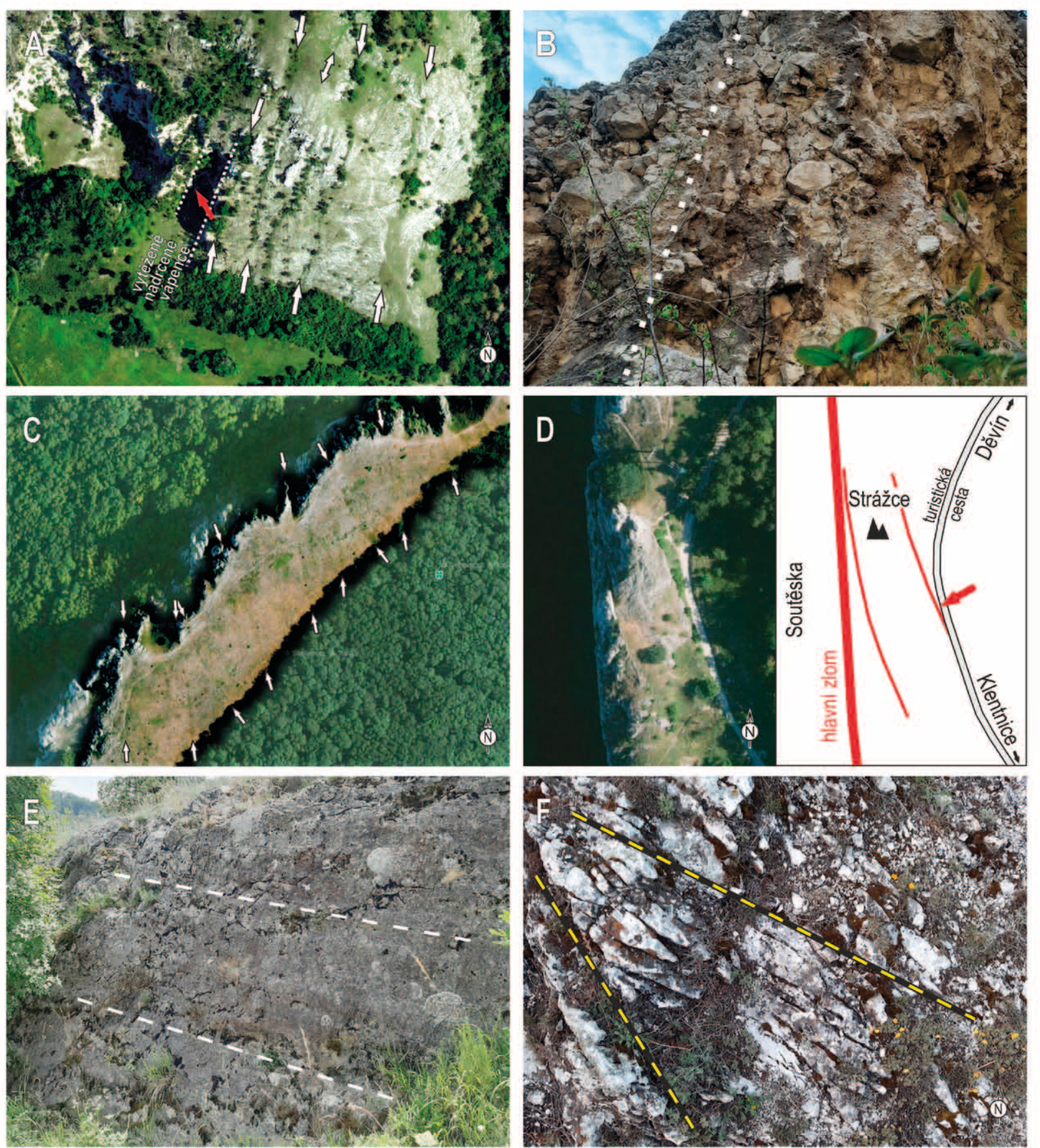

Obr. 3: Doprovodné poruchy hlavního zlomu, paralelní (A, B) a zpeřené (C-F): A - vegetační pásy indikující paralelní poruchové zóny na jihovýchodní straně vrchu Pálava (letecký snímek); B - okraj zóny drcení ve stěně Pastorkova lomu (pozici vyznačuje červená šipka na obr. A): vlevo - silně rozpukaný vápenec, vpravo - tektonická drt’ s tektonicky zaoblenými klasty slabě tmelenými tektonickou drtí; C - vegetační pásy a členitý povrch skalního masivu indikující dva systémy zpeřených poruchových zón na severozápadní straně vrchu Děvín; D - detailní letecký snímek a jeho schéma na západní straně vrchu Děvín; E - subhorizontální rýhování na zpeřeném doprovodném zlomu, západní strana vrchu Děvín (pozici vyznačuje červená šipka na obr. D); F - dva systémy puklinové kliváže ve vápencích, západní strana vrchu Děvín, pohled shora.

Fig. 3: Secondary fractures accompanying the main fault, parallel $(\mathrm{A}, \mathrm{B})$ and oblique $(\mathrm{C}-\mathrm{F})$ : A - vegetation bands indicating parallel fault branches on the south-eastern side of the Pálava Hill (aerial photograph); B - marginal pat of the fault core in the wall of the Pastorek quarry (the position is indicated by the red arrow in Fig. A): left side - strongly fractured limestone in damage zone, right side - tectonic melange of fault core with tectonicly rounded clasts weakly cemented by tectonic dust; C - vegetation bands and rugged surface of the rock massif showing two systems of oblique rupture zones on the northwest side of the Děvín Hill; D - detailed aerial photograph and its scheme on the west side of Děvín Hill; E - subhorizontal striae on the oblique accompanying fault, the western side of the Děvín Hill (the position is indicated by the red arrow in Fig. D); F - two systems of joint cleavage in limestone, west side of Děvín Hill, top view. 
území je posledním projevem sledovaného zlomu drobná elevace Šibeniční vrch, která leží pouze 100 m od česko-rakouských hranic. Tento vrch je podobně jako Kočičí skála úzce protažen ve směru zlomu a indikuje prrítomnost obdobně formované tektonické šupiny.

Vedle hlavní zlomové plochy bylo možno najít i doprovodné paralelní větve sledovaného zlomu. Prvním z míst jsou jihovýchodní svahy vrchu Pálava, kde byly na leteckých snímcích detekovány vegetační pásy zhruba severojižního směru (obr. 3A). Při rekognoskaci na místě bylo zjištěno, že se jedná o terénní rýhy s četnou křovinnou vegetací. Původ těchto rýh bylo možno pozorovat v odkryté stěně opuštěného Pastorkova lomu (lom Perná), odkud je zřejmé, že tyto rýhy představují selektivně erodované drcené poruchy severojižního směru. Ve východní části zmiňovaného lomu je odkryto několik metrů mocné jádro výrazné paralelní větve zlomu, které bylo $\mathrm{s}$ výhodou těženo vzhledem $\mathrm{k}$ velmi silnému tektonickému nadrcení vápence (obr. 3B), které lámání vápence usnadňovalo. Druhým z míst s výraznými paralelními větvemi je západní část Svatého kopečku v Mikulově. $\mathrm{Na}$ stínovaném obrazu reliéfu lze dobře pozorovat nejen tektonické rozdělení vápencového masivu na bloky podle paralelních zlomových větví, ale také nápadné levostranné posunutí jednotlivých tektonických bloků, což umožňuje jednoznačně definovat sledovaný zlom jako levostranný horizontální posun (obr. 2D).

Na leteckých snímcích, ale i v modelu reliéfu bylo možno najít i křehké zpeřené poruchy, které probíhají šikmo k hlavní zlomové ploše. V modelu reliéfu je lze detekovat zejména v jz. a sv. omezení Stolové hory a skal

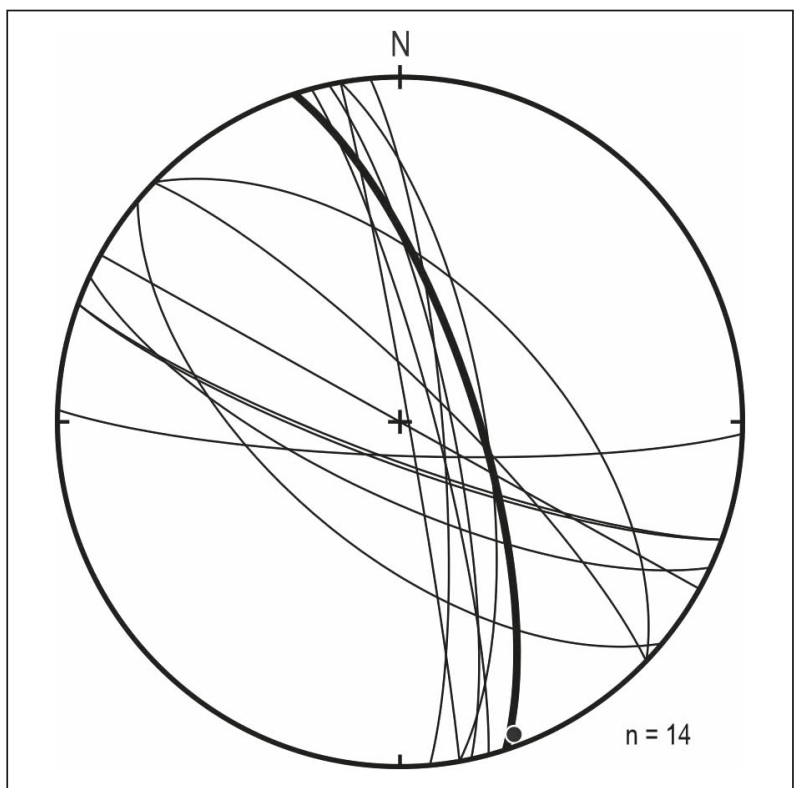

Obr. 4: Orientace doprovodných struktur západní a severozápadní strany vrchu Děvína: tučný oblouk a kroužek - plocha zlomu se subhorizontální lineací; tenké oblouky - puklinová kliváž. Rovnoplochá azimutální projekce na spodní polokouli. Fig. 4: Orientation of the fractures accompanying the main fault in the western and northwestern side of Děvín Hill: bold circle and dot - fault surface with subhorizontal striation; thin circle - joint cleavage. Equal-area azimuthal projection on the lower hemisphere.
Sirotčího hrádku u Klentnice, a také v průběhu tenké tektonické šupiny Klentnické skály mezi oběma zmiňovanými elevacemi. Mnohem rozsáhlejší rozšíření těchto kosých poruch však ukázaly letecké snímky, na kterých bylo možno tyto struktury identifikovat na místech s víceméně obnaženým povrchem, kde je indikují úzké vegetační pásy. Pásy vegetace orientované zpravidla pod úhly zhruba $15^{\circ}$ a $75^{\circ}$ vůči vymezenému průběhu zlomu jsou dobře viditelné např. na bezlesé severozápadní straně vrchu Děvín (obr. 3C). Jejich tektonická podmíněnost se projevuje i v morfologickém omezení skalního okraje, které koresponduje s protažením těchto pásem. Terénní rekognoskací bylo zjištěno, že většina ploch z těchto morfologických projevů je silně ovětralá, avšak v zářezu cesty podél západní hrany vrchu Děvín byla těsně pod vyhlídkou Strážce nalezena drobná strmě orientovaná zlomová plocha, na níž bylo možno alespoň částečně stanovit její kinematický charakter (obr. 3D). Tento drobný doprovodný zlom svírá s hlavním zlomovým omezením Soutěsky úhel $15^{\circ}$. Rýhování, které bylo možno na zlomové ploše pozorovat, je subhorizontálně orientované (obr. 3E, 4). Jedná se tedy o horizontální posun, avšak smysl pohybu nebylo možno spolehlivě určit vzhledem k silnému ovětrání zlomové plochy.

Vedle popsaného doprovodného zlomu bylo terénní rekognoskací v této části Děvína zjištěno rozsáhlé zbřidličnatění vápenců charakteru puklinové kliváže (obr. 3F, 4) orientované ve stejných směrech, jako mají zmiňované vegetační pásy. Zajímavým projevem puklinové kliváže je zvýšení odolnosti vápenců vůči zvětrávání, což se projevuje vznikem tzv. puklinových škrapů, které popsal Vítek (2013). Srovnatelné pásy porušení zvýrazněné vegetací a podobné porušení vápenců bylo možno pozorovat i na Svatém kopečku a dalších nezalesněných místech.

\section{Diskuze a závěrečné shrnutí}

Výše uvedená morfologická indikace křehkého porušení ukazuje na téměř spojitý průběh zlomu zhruba severojižního směru, který probíhá od Horních Věstonic na severu po Mikulov na jihu a dále pokračuje do Rakouska. Uvedený zlom lze částečně ztotožnit s falkensteinsko-mikulovským zlomem, k němuž však přiřazujeme i další severní pokračování do oblasti Soutěsky. V podrobné mapě dle Čtyrokého et al. (1988) má falkensteinsko-mikulovský zlom smèr SSV-JJZ a je situován na západní okraj Svatého Kopečku, kde zalomeně mění směr a dále probíhá severojižně. Nově hlavní větev tohoto zlomu situujeme poněkud západněji do prostoru zóny tektonických šupin probíhající od Šibeničního vrchu, přes zámecký vrch, Čertův kámen a Turold až po Kočičí skálu. Izolované a vzájemně nenavazující tektonické šupiny ukazují na významný tektonický pohyb podél této zóny, řádově větší než ukazují poruchy s navazujícími stavbami při západním ukončení Svatého kopečku, které považujeme za doprovodné paralelní větve hlavního zlomu. $Z$ tvaru tektonických šupin a z nich odvozeného průběhu hlavní zlomové zóny je zřejmé, že se nejedná o jednoduchou zlomovou plochu, ale že se zlomová plocha směrně 
anastomózně větví a spojuje za vzniku zmiňovaných tektonických šupin.

Kinematický charakter zlomu lze odvodit především podle doprovodných struktur, a to jak těch zpeřených, tak i paralelních. Nalezené doprovodné zpeřené poruchy směrů SSZ-JJV a ZSZ-VJV interpretujeme jako dva systémy Riedlových střihů pod očekávanými úhly $15^{\circ}$ a $75^{\circ} \mathrm{k}$ průběhu hlavního zlomu. Jejich subvertikální orientace a nalezené subhorizontální rýhování jsou kompatibilní s touto interpretací a charakterizují popisovaný zlom jako levostranný horizontální posun. To je v souladu i s morfologicky viditelnými posuny bloků podél paralelních doprovodných zlomů př̀ západním omezení Svatého kopečku.

O stáří tektonických pohybů podél popsaného zlomu lze spekulovat na základě vztahů k jiným strukturám $s$ přihlédnutím $\mathrm{k}$ možnému vývoji napjatostního pole. Zlom je predatován vznikem příkrovové stavby akrečního klínu Vnějších Západních Karpat, nebot zlom porušuje alochtonní vápencová tělesa. Vzhledem k blízkému kinematickému charakteru násunových pohybů (levostranné násuny) a popisovaného zlomu (levostranný posun) lze předpokládat, že nejvýznamnější pohyb podél popisovaného zlomu těsně navazoval na násunové pohyby při závěrečném formování karpatského akrečního klínu, tj. zlom se zřejmě formoval ještě během pohybu Karpat k severu. Fixaci velkých levostranných pohybů dokládá zlomové pásmo Hané směru SZ-JV, které nepřerušeně probíhá z Českého masivu do Vnějších západních Karpat a které omezuje tektonickou depresi Hornomoravského úvalu vyplněnou pliocenními sedimenty. K hlavnímu pohybu tak došlo nejspíše v pozdním miocénu, přičemž nelze vyloučit i pozdější reaktivace.

\section{Poděkování}

Výzkum byl podpořen programem dlouhodobého koncepčního rozvoje výzkumné organizace RVO: 67985891. Autoři děkují za pripomínky editorovi M. Geršlovi a recenzentưm J. Havírovi a J. Rezovi.

Literatura

Adámek, J. (1979). Závěrečná zpráva o hlubokém strukturním vrtu Strachotín-2. - MS, Moravské Naftové Doly. Hodonín.

Adámek, J., Bimka, J., Chmelík, F. (1984). Vyhledávací průzkum v jižní části karpatské neogenní předhlubně a jejím hlubinném podkladu v širší oblasti Pohořelic. - MS, Moravské Naftové Doly. Hodonín.

ČÚZK (2021). Analýzy výškopisu. DMR 5G. Stínovaný reliéf. - Dostupné na: https://ags.cuzk.cz/av/. 25. 8. 2021.

Čtyroký, P., Havlíček, P., Dornič, J., Stráník, Z., Zeman, A. (1988). Základní geologická mapa ČSSR - List 34-142 Mikulov. Ústřední ústav geologický. Praha.

Dudek, A., Špička, V. (1975). Geologie krystalinika v podloží karpatské předhlubně a flyšových příkrovů na jižní Moravě. - Sborník geologických věd, Geologie, 27, 7-29. Praha.

Jüttner, K. (1933). Zur Stratigraphie und Tektonik des Mesozoikums der Pollauer Berge. - Verhandlungen des naturforschenden Vereines in Brünn, 64, 15-31. https://www.zobodat.at/pdf/Verh-naturf-Ver-Bruenn_64_0015-0031.pdf.

Kalášek, J., red. (1963). Vysvětlivky k přehledné geologické mapě ČSSR 1 : 200000 M-33-XXIX Brno. - Československá akademie věd. Praha.

Mapy.cz (2021). Letecká mapa (ortofotomapa). - Dostupné na: https://mapy.cz/ , 25. 8. 2021.

Poul, I. (2004): Paleonapjatostní analýza zlomů Pavlovských vrchů Západní Karpaty. - MS, diplomová práce. Přírodovědecká fakulta Masarykovy univerzita. Brno.

Poul, I. (2006): Nový tektonický model model Pavlovských vrchů: flat-ramp-flat geometrie v externích Západních Karpatech. MS, rigorózní práce. Př́rodovědecká fakulta Masarykovy univerzita. Brno.

Poul, I., Melichar, R. (2009). Orientace příčných zlomů v Pavlovských vrchách na jižní Moravě (Západní Karpaty). - Geologické výzkumy na Moravě a ve Slezsku, 16, 70-74. https://journals.muni.cz/gvms/article/view/4783.

Rajnoch, A. (2021): Interpretace vybraných seismických řezů v oblasti Vnějších Západních Karpat na jižní Moravě. - MS, bakalářská práce. Př́rodovědecká fakulta Masarykovy univerzity. Brno.

Rez, J. (2020). StaTect - aplikace na zpracování kompasových dat. - Dostupné na: http://www.eltekto.cz/. 25. 8. 2021.

Stejskal, J. (1934). Geologická stavba Pavlovských vrchů na jižní Moravě. Část I. Stratigrafie. - Věstník Státního geologického ústavu Československé republiky, 10, 6, 199-209. Praha.

Stejskal, J. (1935). Geologická stavba Pavlovských vrchů se žretelem na stratigrafii a tektoniku flyše. Č́st II. - Věstník Státního geologického ústavu Československé republiky, 11, 1-2, 15-29. Praha.

Stráník, Z., Adámek, J., Ciprys, V. (1979). Geologický profil karpatskou předhlubní, flyšovým pásmem a vídeňskou pánví v oblasti Pavlovských vrchů - In: Mahel', M. (ed.): Tektonické profily Západných Karpát, 7-14. Geologický Ústav Dionýza Štúra. Bratislava.

Stráník, Z., Čtyroký, P., Havlíček, P. (1999). Geologická minulost Pavlovských vrchů. - Sborník geologických věd, Geologie, 49, 5-32. http://www.geology.cz/sbornik/geologie/no49/49-1-geologicka...pdf.

Vítek, J. (2013). Škrapy ve vápencích Pavlovských vrchů. - Acta Musei Moraviae, Scientiae Geologicae, 1, 91-109. http://scigeo. actamm.cz/wp-content/uploads/2019/05/2013-1-091-vitek.pdf. 